\title{
Three necessary conditions for establishing effective Sustainable Development Goals in the Anthropocene
}

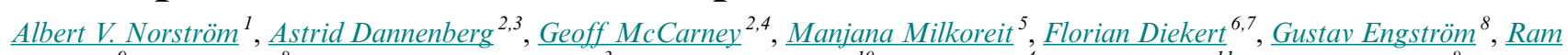 \\ $\underline{\text { Fishman }}^{9}, \underline{\text { Johan Gars }}^{8}$, Efthvmia Kvriakopoolou $^{3}$, Vassiliki Manoussi $^{10}$, Kvle Meng $^{4}$, Marc Metian $^{11}$, Mark Sanctuary $^{8}, \underline{\text { Maja }}$ \\ Schlüter $^{1}$, Michael Schoon $^{5}$, Lisen Schultz $^{1}$ and Martin Sjöstedt ${ }^{12}$
}

\begin{abstract}
The purpose of the United Nations-guided process to establish Sustainable Development Goals is to galvanize governments and civil society to rise to the interlinked environmental, societal, and economic challenges we face in the Anthropocene. We argue that the process of setting Sustainable Development Goals should take three key aspects into consideration. First, it should embrace an integrated social-ecological system perspective and acknowledge the key dynamics that such systems entail, including the role of ecosystems in sustaining human wellbeing, multiple cross-scale interactions, and uncertain thresholds. Second, the process needs to address trade-offs between the ambition of goals and the feasibility in reaching them, recognizing biophysical, social, and political constraints. Third, the goal-setting exercise and the management of goal implementation need to be guided by existing knowledge about the principles, dynamics, and constraints of social change processes at all scales, from the individual to the global. Combining these three aspects will increase the chances of establishing and achieving effective Sustainable Development Goals.
\end{abstract}

Key Words: social change; social-ecological systems; Sustainable Development Goals; transformations

\section{INTRODUCTION}

There is a broad and active process to develop a set of Sustainable Development Goals (SDGs) to succeed the expiring United Nations (UN) Millennium Development Goals (MDGs) (http:// tracker.post2015.org provides an online repository of all the publicly available proposals for future SDGs). The decision to establish SDGs was made at the UN Rio+20 conference, based on a proposal by the governments of Colombia, Guatemala, and Peru. Nations and international organizations are now working to define what such goals should be, with the UN playing an important role in these developments. Three of the SDG-linked initiatives are the Open Working Group on Sustainable Development Goals (a 30-member group of the UN General Assembly that was established in January 2013 with the objective to prepare a proposal on SDGs and report back to the General Assembly in 2014), the High Level Panel of Eminent Persons on the post-2015 agenda, and the Sustainable Development Solutions Network. A priority is to identify a post-2015 agenda, as 2015 is the year the MDG objectives are to be achieved. The MDGs have been successful in focusing efforts on, and encouraging a global political consensus around, issues such as hunger, gender inequality, poverty, and disease. A key to their success is that the MDGs are a short list of clear and coherent goals that have focused on well-recognized global problems. Initial indications suggest that the SDGs will also be structured as a relatively short set of coherent, aspirational goals. Various political actors have put forward proposals containing different numbers and types of goals, but most proposals seem to be consolidating around the core issues of poverty, gender equality, education, health, food security, water and sanitation, energy, jobs, natural resources, governance, and climate change. However, the MDGs have been criticized for their narrow focus on the human aspects of development, while overlooking the importance of natural capital and ecosystem services (Waage et al. 2010). Further, the existing MDG framework fails to capture the complex interdependencies between the goals, and there is little cross-referencing between targets and indicators (Waage et al. 2010). The MDGs have also been criticized for placing obligations only on developing countries, and for not having the universal ambition of transforming sustainability pathways.

The new goals are likely to expand the MDGs (Sachs 2012), but if the SDGs are to galvanize governments and civil society to confront the interlinked social, economic, and ecological challenges of the Anthropocene (Steffen et al. 2011), they need to avoid the shortcomings of the MDGs (Griggs et al. 2013). The Anthropocene is the new geological epoch (Crutzen 2002), which is characterized by humanity having become the dominant force of planetary change (Steffen et al. 2011). Today, humans are changing the composition of the Earth's atmosphere (IPCC 2013), have modified or transformed most of the Earths' terrestrial and marine ecosystems (Halpern et al. 2008, Ellis et al. 2010), have substantially altered the flows of fresh water (Vörösmarty et al. 2010), have changed elemental cycles and flows of mineral resources (Steffen et al. 2004), and have radically changed the distribution of plants and animals (MEA 2006). By many measures, the changes humanity has caused in the last 50 years are now at or beyond the variations seen through the entire Holocene - the present geological era starting 10,000 years ago that has provided the relatively stable environment that has enabled humanity's development of agriculture and complex societies. At the same time, people are fundamentally dependent

${ }^{1}$ Stockholm Resilience Centre, Stockholm University, Sweden, ${ }^{2}$ The Earth Institute, Columbia University, USA, ${ }^{3}$ Dept. of Economics, University of Gothenburg, Sweden, ${ }^{4}$ School of International and Public Affairs, Columbia University, USA, ${ }^{5}$ School of Sustainability, Arizona State University, USA, ${ }^{6}$ Dept. of Economics, University of Oslo, Norway, ${ }^{7}$ NoRMER/CEES, Dept. of Biology, University of Oslo, Norway, ${ }^{8}$ The Beijer Institute of Ecological Economics, The Royal Swedish Academy of Science, Sweden, ${ }^{9}$ Dept. of Economics, George Washington University, USA, ${ }^{10}$ Athens University of Economics and Business, Greece, ${ }^{11}$ Radioecology Laboratory, IAEA Environment Laboratories, Monaco, ${ }^{12}$ Dept. of Political Science, University of Gothenburg, Sweden 
on the capacity of the biosphere to provide services for human wellbeing and societal development (MEA 2006). As the human population continues to grow and the ecological and environmental impacts of human economic activity increase, our effect on the biosphere could threaten to exceed vital planetary boundaries (Rockström et al. 2009), beyond which critical tipping points in the Earth System may be transgressed (Barnosky et al. 2012, Hughes et al. 2013). Navigating the Anthropocene in order to steer away from such thresholds will require major shifts in values and beliefs, patterns of social behavior, and multilevel governance and management regimes (Biermann et al. 2010). Clearly, the complex governance demands of the Anthropocene provide an important context for the framing of the future SDGs but clash with the idea of simple, modular goals for specific, bounded development problems.

We argue that the formulation, substance, and implementation of the SDGs should be framed by three key insights from a growing transdisciplinary body of work that is fusing ecology, economics, psychology, global governance, and socio-technological systems studies. First, human and natural systems are inseparably linked and nested across scales, and should be dealt with as socialecological systems. Second, SDGs must acknowledge and navigate trade-offs between goal ambition and goal feasibility. Third, both the formulation of the SDGs and all implementation efforts should be guided by existing knowledge about the drivers, dynamics, and limitations of social change processes at all scales, from the individual to the global. In the remainder, we discuss some of the key implications these three insights should have for the formulation and implementation of the SDGs.

\section{A SOCIAL-ECOLOGICAL SYSTEMS APPROACH}

Ecological, economic, and social systems are increasingly viewed as interlinked and inseparable social-ecological systems (Berkes and Folke 1998, Ostrom 2009, Folke et al. 2011). Mounting research is showing that people are part of ecosystems and shape them, from local to global scales, and are at the same time fundamentally dependent on the capacity of these systems to provide services for human wellbeing and societal development. Ecosystem services are the benefits that natural ecosystems provide to people, and are often distinguished as (1) provisioning services, such as food production; (2) regulating services, such as flood defense, which maintain a resilient environment and protect against environmental disturbance; (3) cultural services, which are reflected in religious, recreational, or cultural values and practices; and (4) supporting services, which comprise the underlying ecological structures and processes on which all other services rely. SDGs should be designed to enhance the awareness of, and focus on, the role of ecosystem services within (not alongside) economic development and poverty reduction. Similarly, targets for SDGs that are focused on the environment need to be formulated not only in favor of preserving the biosphere but also to ensure continued societal development. This would align the SDGs with the increasing calls by global policy fora and agencies (e.g., Convention on Biological Diversity, World Food Summit, DIVERSITAS, IUCN, UNESCO, UNEP) that actions to enhance the supply and reliability of ecosystems services are urgently needed at local, regional, and global scales (MEA 2006, Daily et al. 2009, Perrings et al. 2011, Larigauderie et al. 2012, Reyers et al. 2013). The newly established Intergovernmental Platform on Biodiversity and Ecosystem Services can play a critical role in addressing the needs of the SDG framework to incorporate knowledge about the complex relationship between ecosystem services and human society.

In the Anthropocene, the spatial and temporal scales of interdependency between human and ecological systems are changing profoundly (Young et al. 2006, Helbing 2013). Processes such as human migration, trade, transnational land acquisitions, spread of invasive species, and technology transfer are now more prevalent and occur more quickly than ever before, facilitated by a global infrastructure for the movement of people, goods, services, diseases, and information (Butchart et al. 2010, Steffen et al. 2011, Davis et al. 2013). Because of this increasingly tight coupling of distant systems through social-ecological linkages, actions taken in seemingly independent places affect the interlinked global social-ecological system in unexpected ways, with surprising mixes of immediate consequences as well as cascading and distant effects (Biggs et al. 2011, Meyfroidt et al. 2013). For example, addressing climate change goals through biofuel investments in one place may increase global greenhouse gas emissions and threaten local food security due to indirect land use changes in remote locations (Searchinger et al. 2008). Similarly, successfully increasing food production and biodiversity conservation in one region, and navigating the tradeoff between these dual goals, can result in unsustainable land use change being displaced and adding pressure to social-ecological systems in distant regions (Lambin and Meyfroidt 2011). Clearly, the SDGs must avoid becoming a collection of single issue-based objectives, as in the case of the MDGs. For example, Griggs et al. (2013) suggest six SDGs that address trade-offs and synergies between goals, and that are formulated around the twin priorities of protecting the Earth's life-support system and the reduction of poverty. These goals - thriving lives and livelihoods, food security, water security, clean energy, healthy and productive ecosystems, governance, and sustainable societies - do not simply extend the MDGs, as some are suggesting, but explicitly put them into a social-ecological context, where sustainable development is redefined as "development that meets the needs of the present while safeguarding Earth's life-support system, on which the welfare of current and future generations depends" (Griggs et al. 2013). Explicitly linking interconnections, trade-offs, and synergies between goals and targets will have many benefits of reducing the costs of action as well as avoiding unintended socialecological consequences. Emerging approaches that support the assessment of indirect impacts and systemic interconnections in the Anthropocene can facilitate this (Walker et al. 2009, Seto et al. 2012, Meyfroidt et al. 2013). For example, biophysical accounting and economic simulation models (e.g., computable general equilibrium models) provide analytical frameworks for projecting the global cropland displacement associated with different national land use policies, and assessing the mechanisms causing this (Hertel et al. 2010, Villoria and Hertel 2011). Climate adaptation frameworks are now beginning to look at tools from the private sector, such as supply chain risk assessments, to incorporate indirect impacts and climate risks that originate outside national borders and that are transmitted by biophysical, trade, financial, and human migration pathways (Benzie et al. 2013). Finally, the agendas of new international and interdisciplinary science initiatives such as FuturICT and Future Earth are explicitly focusing on refining existing, and developing 
new, tools to further our knowledge about global interactions and interdependencies between social, technological, and environmental systems; importantly, these communities are ready to participate in the codesign of the SDGs and related measures (Reid et al. 2010, Brito 2012, Paolucci et al. 2012).

The SDGs need also to move beyond the traditional approach to development that assumes stability and linear changes in social, ecological, and economic systems. Social-ecological systems often exhibit unpredictable and nonlinear behavior as a result of key processes or subsystems crossing over critical thresholds. For example, there is now substantial experimental, modeling, and empirical evidence showing unexpected and nonlinear changes in ecosystems (Scheffer et al. 2001, Barnosky et al. 2012) and the services they generate (Bennett et al. 2009), collective action in common pool resources (Lade et al. 2013), financial markets (Kambhu et al. 2007), climate (Lenton et al. 2008), and human value and belief systems (Brock et al. 2003). To deal with complex, often surprising, social-ecological behavior, SDGs need to be measurable and embedded in an adaptive governance context (Folke et al. 2005) that allows for iterative adjustments of goals and strategies when situations change or new knowledge becomes available. Measuring and monitoring progress on the SDGs will require agreed upon sets of multidimensional indicators that make sense at national, regional, and international levels. While the difficulties of creating measurable, multidimensional policy targets have been highlighted in the past (Parris and Kates 2003a, Attaran 2005), recent social-ecological systems-based approaches for measuring multiple ecosystem services and human wellbeing provide hopeful avenues for developing integrated and scalable indicators for global international agreements, such as the SDGs. For example, Reyers et al. (2013) use such a framework to develop indicators for measuring progress toward Target 14 of the Convention on Biological Diversity (CBD) current strategy (CBD Target 14 -By 2020, ecosystems that provide essential services including services related to water, and contribute to health, livelihoods and well-being, are restored and safeguarded, taking into account the needs of women, indigenous and local communities and the poor and vulnerable"). This complex target is distilled into its component parts (e.g., focal beneficiary groups, relevant ecosystem services, benefit flows, social-ecological factors, governance and management settings), and sets of measures that can evaluate progress within each component are highlighted. Complementary strategies, such as investments in globally harmonized real-time data collecting and reporting systems (Pereira et al. 2013) for SDGs, alongside institutions that foster learning and allow rapid feedback to decision-makers, can provide the capacity to shift implementation pathways or SDGs when progress is off track or data indicate that certain systems are approaching thresholds.

\section{TRADE-OFFS BETWEEN AMBITION AND FEASIBILITY}

The outcome document of the Rio+20 conference states that the SDGs should be ambitious and universally applicable, and should take into account capacities and priorities of countries. However, just like the MDGs, the SDGs will be a set of moral and political commitments, as opposed to legally binding ones. While countries may agree on a set of ambitious, universal goals, they cannot be forced to comply with them. The incentives for individual countries to free ride on others' efforts will exist in the absence of global regulatory and enforcement mechanisms. Successful SDGs will require generating collective action around them and minimizing free riding. Experimental and field studies provide encouraging results from, mostly small-scale, communities that were able to establish and maintain high levels of cooperation through mutual agreements, even without external sanction and enforcement institutions (Ostrom 1990, Ostrom et al. 2002, Janssen et al. 2010, Poteete et al. 2010). However, the success of such voluntary agreements depends on whether goals are credible and transparent, and whether noncompliance imposes sufficiently high social costs on most members. It is unclear whether such cooperation can materialize and ensure compliance around the SDGs, which are global collective action problems. There are indications that self-organizing and polycentric approaches can emerge as ways to deal with other transnational and regional collective action problems such as climate governance (Ostrom 2010), public health (Lieberman 2011), ocean acidification (Galaz et al. 2012), and fisheries overexploitation (Österblom and Sumaila 2011) when enforceable global agreements are missing or have failed. Polycentric approaches refer to multiactor and multilevel responses that are characterized by a self-organizing relationship between many centers of decision-making that are formally independent of each other. These governance configurations seem to facilitate experimentation, cooperation, and learning at multiple levels (Ostrom 1999), which are prerequisites for dealing with problems that cut across administrative domains (Galaz et al. 2008), uncertainty, and complex system behavior (Folke et al. 2005). Ostrom (2010) argues that the various innovative interventions to reduce greenhouse gas emissions occurring at local, national, and regional levels (e.g., the large networks of cities across multiple countries that have pledged to reduce greenhouse gas emissions, the 2006 California Global Warming Solutions Act, and the EU Emissions Trading Scheme) are part of an emerging and expanding polycentric arrangement. The seeds of polycentric arrangements that could emerge around the SDGs could be found in the existing efforts to implement sustainable development at multiple scales in businesses, communities, and nations. A polycentric arrangement to the SDGs could be facilitated further if this process were informed by ongoing stocktaking efforts of how existing interenvironmental agreements and/or policy targets can be incorporated into the SDGs (UNEP 2012, Schultz et al. 2013).

While polycentric order holds promise, we still know very little about the features and conditions that trigger and maintain these governance arrangements and whether they can be fully designed from scratch or must evolve organically (Galaz et al. 2012). Moreover, polycentric approaches will not suffice in isolation; they will always be dependent on anchoring with more formal negotiation processes (Galaz et al. 2012). Therefore, it is indispensable to stimulate collective action around the SDGs by negotiating strategic agreements (Barrett 2003), meaning that the SDG targets do not aim at what we should do but rather at what we can do. In other words, the trade-offs between ambition and feasibility will need to be navigated. A track record of "secondbest" solutions may be a way to establish behavioral norms and the spirit needed to tackle more ambitious targets in the future. A good example is the International Convention for the Prevention of Pollution from Ships (known as MARPOL), a technology standard for oil tankers that helped overcome the free 
riding problem and has significantly improved over time (Barrett 2003). Combining an appreciation of the polycentric nature of governance with an acknowledgement of the trade-off between ambition and feasibility means that SDGs need to be scalable. This is perhaps best exemplified by the slogan "think global, act local." SDGs should enable actors to feel responsible and should motivate them to push for positive change. This will not be achieved if the bar is set either too high or too low.

\section{PROCESSES OF SOCIAL CHANGE}

Scientists concerned about the future of the planet routinely conceptualize current development trajectories as being "locked in" unsustainable pathways (Brock et al. 2003, Brock and Carpenter 2007, Folke et al. 2011). Consequently, there has been growing interest in understanding and stimulating sustainability transitions or transformations in the Anthropocene so that socialecological systems are set on new trajectories that ensure that both human wellbeing and a range of ecosystem services are sustained over time (Parris and Kates 2003b, Chapin et al. 2010, Grin et al. 2010, Westley et al. 2011, Leach et al. 2012). Such transformations may require radical, systemic shifts in deeply held values and beliefs, patterns of social behavior, and multilevel governance and management regimes. The SDGs can play a critical role in accelerating and measuring progress toward such sustainable development trajectories. However, goal-setting per se does not ensure that change will happen, regardless of the motivational power of the goals set. SDGs could catalyze and maintain transformational change, opening a window of opportunity for creating appropriate norms, institutions, and incentive structures for social innovations. This requires the SDG implementation framework to be guided by existing knowledge about the characteristics, dynamics, and limitations of social change processes at all scales, from the individual to the global. We can address only a small subset of these issues; our arguments are limited to the role of shared belief systems and their differences across communities and societies, the importance of understanding and leveraging institutions and institutional change, and finally, the need to accelerate social innovation through the creation of experimental settings associated with institutionalized opportunities for scaling up success stories.

Substantial headway has been made in understanding how shared belief systems in social groups (such as communities, states, or markets) emerge. Collective belief systems provide the foundation for (national) identities or interests, and can shape or change norms and guide decisions (Finnemore and Sikkink 1998, Pinker 2006). They can, for example, determine why a government selects one policy option rather than another, or how different stakeholders in a national park respond to alternative management goals. The sharp divide between liberals and conservatives in the United States regarding the appropriate political response to climate change illustrates the importance of shared belief and value systems for addressing sustainable development challenges. A recent study by Gromet et al. (2013) highlights the importance of taking into account belief systems (in this case, political ideologies) when trying to facilitate sustainability policies like increasing the use of more energy efficient products. The authors found that connecting energy efficient products to environmental concerns can negatively affect the demand for these products in the United States, specifically among persons who are more politically conservative. Other studies provide evidence that citizen support for renewable energy can be garnered through linking relevant policy measures to job creation (Espinoza and Vredenburg 2010). Accounting for existing belief systems and norms at various social scales can improve the design and implementation of SDGs by highlighting potential constraints but also providing the "construction materials" for better national-scale targets and incentives beneath each goal. In this way, community-specific circumstances serve as a starting point for change. National targets could be formulated in ways that resonate with key belief systems and avoid counterproductive consequences due to ideological polarization. For example, in some instances, it could require targets that place a higher emphasis on themes like energy independence, air quality, and economic opportunity, and less emphasis on environmental, ecological, or climate change-related frames. A key challenge for science is to begin disentangling how these cognitive issues play out at different social scales (local, regional, and national) in different countries - since the relevant value and belief systems will be different. Building and acting on this knowledge will require the establishment of multilevel support and advisory systems that can help identify the nation-specific communication and framing challenges when developing the respective SDG implementation strategies jointly with national governments and civil society institutions.

Institutions, the formal rules and informal norms that shape human behavior, provide the broader foundations for collective social change (Finnemore and Sikkink 1998). However, institutions are often prone to inertia and difficult to transform (Rothstein 2000), which suggests that SDGs that propose significant institutional change may meet with resistance or noncompliance. The formulation and pursuit of SDGs has to take such inertia into consideration and assess trade-offs between staggered institutional reform and creation from scratch. This suggests that any SDG proposals that require significant institutional change should also include incentives to overcome such inertia and modify the cost-benefit calculus. Ostrom et al. (1994) provide empirical and experimental examples of institutional changes in incentive structures leading to behavioral differences in outcomes. At the international level, a historic example involves the North Pacific Fur Seal, in which a regime of collaboration emerged that eliminated pelagic harvests in exchange for a managed and coordinated shared harvest (Young 1994). The fractionalized harvest and agreed upon elimination of pelagic hunting changed the calculus of the trade in fur seals, and resulted in a sustained rebound in populations for more than 70 years. Setting targets as particular, more modest changes that provide good incentives for subsequent shifts in governance (e.g., towards greater openness or transparency) might be an effective approach in such cases. The building of formal $\mathrm{CO}_{2}$ accounting and reporting practices into international climate agreements is a good example of this type of approach (Lovell and MacKenzie 2011), since formal reporting requirements can provide simple incentives that can lead to subsequent changes in behavior.

Transformational change can be accelerated and triggered through social innovations, in the form of new sets of rules and norms, new ways of thinking, and new processes for action and decision-making (van der Leeuw 2010, Westley and Antadze 2010). While the SDGs cannot demand or predict such social innovations, they can create social innovation spaces and be 
designed to integrate the results from these innovation spaces with processes of adaptive goal setting and goal pursuit. In the literature on socio-technical transitions (Grin et al. 2010), the concept of transformative niches or transition arenas has been used to describe spaces where new social innovations are tested and developed (Smith and Raven 2010, Seyfang and Haxeltine 2012). These "protected" spaces provide support for experimentation, and are used to develop new substance (ideas, agendas visions), to support a process (of network/coalition building, learning), and to subtly influence the dominant rule sets supported by incumbent social networks and organizations (Loorbach and Rotmans 2010). Recent studies from regional to international scales, and across different types of institutions, give evidence that such innovation spaces can play a key role in facilitating transformative change (Loorbach and Rotmans 2010). Such spaces need to have clear boundaries and purposes in order to catalyze ideas in a certain direction, while leaving room for experimentation, local adaptation, and failure. Incentives and enabling conditions for global networks of problem solving "policy laboratories" and "innovation change labs" can be one pathway. Such networks will integrate different perspectives and knowledge sets, and facilitate breakthroughs in complex problem domains toward more sustainable policy and management options (Westley et al. 2011).

\section{CONCLUSION}

The desire to formulate SDGs as successors to the MDGs signals that global priorities are headed in the right direction. There are of course many other contentious and multifaceted issues that need to be navigated by the SDG process; for example, issues of equity, the contested relationship between "good governance" and sustainability, and the visibility unevenness of certain social groups (Wolbring et al. 2013). However, the Anthropocene poses particular challenges for how a strong and legitimate successor to the MDGs needs to be designed and formulated. Critically, a set of SDGs that ignores a social-ecological perspective, critical trade-offs between feasibility and ambition, and agents of social change would lead to contradictory and ill-defined objectives.

Ultimately, the process of developing SDGs needs to stem from a broad and inclusive vision and common analysis of what we want to achieve. While MDGs focused on developing countries, SDGs need buy-in from all nations. An achievable and shared set of SDGs must inspire public support, and needs to be taken and implemented at multiple levels of governance. Such a universal set of SDGs needs to stem from a broad participatory process and inclusive vision of the future that allows for deliberation between science and societal actors. Considering the rapid development of information technologies, there is an unprecedented opportunity to build a highly energized network that engages the world's governments, scientific communities, business, and civil society in inclusive, global-scale collaboration on formulating and identifying SDGs and the pathways needed to reach them. Such a global visioning process is already underway, for example, in the UN-led consultation processes that are being carried out on national ( 88 national consultations) and global (11 global thematic consultations) scales and through global online platforms (e.g., http://www.worldwewant2015.org/).
Responses to this article can be read online at: http://www.ecologyandsociety.org/issues/responses. $\mathrm{php} / 6602$

\section{Acknowledgments:}

Scott Barrett, Carl Folke, Victor Galaz, and Maria Schultz reviewed an earlier draft. We thank the Beijer Institute of Ecological Economics, the Kjell and Märta Beijer Foundation, and the AnnaGreta and Holger Crafoord Foundation for hosting and funding the Beijer Young Scholars network and the Beijer Young Scholars Fejan workshop.

\section{LITERATURE CITED}

Attaran, A. 2005. An immeasurable crisis? A criticism of the Millennium Development Goals and why they cannot be measured. PLoS Medicine 2:e318. http://dx.doi.org/10.1371/ journal.pmed.0020318

Barnosky, A. D., E. A. Hadly, J. Bascompte, E. L. Berlow, J. H. Brown, M. Fortelius, W. M. Getz, J. Harte, A. Hastings, P. A. Marquet, N. D. Martinez, A. Mooers, P. Roopnarine, G. Vermeij, J. W. Williams, R. Gillespie, J. Kitzes, C. Marshall, N. Matzke, D. P. Mindell, E. Revilla, and A. B. Smith. 2012. Approaching a state shift in Earth's biosphere. Nature 486:52-58. http://dx.doi. org/10.1038/nature11018

Barrett, S. 2003. Environment and statecraft: the strategy of environmental treaty-making. Oxford University Press, New York, USA.

Bennett, E. M., G. D. Peterson, and L. J. Gordon. 2009. Understanding relationships among multiple ecosystem services. Ecology Letters 12(12):1394-1404. http://dx.doi.org/10.1111/ j.1461-0248.2009.01387.X

Benzie, M., O. Wallgren, and M. Davies. 2013. Adaptation without borders? How understanding indirect impacts could change countries approach to climate risks. Stockholm Environment Institute Discussion Brief, Stockholm, Sweden.

Berkes, F., and C. Folke. 1998. Linking social and ecological systems: management practices and social mechanisms for building resilience. Cambridge University Press, Cambridge, UK.

Biermann, F., M. M. Betsill, S. C. Vieira, J. Gupta, N. Kanie, L. Lebel, D. Liverman, H. Schroeder, B. Siebenh $\tilde{A}^{1 / 4} / 4$ er, P. Z. Yanda, and R. Zondervan. 2010. Navigating the Anthropocene: the Earth System Governance Project strategy paper. Current Opinion in Environmental Sustainability 2:202-208. http://dx.doi.org/10.1016/ j.cosust.2010.04.005

Biggs, D., R. Biggs, V. Dakos, R. J. Scholes, and M. Schoon. 2011. Are we entering an era of concatenated global crisis. Ecology and Society 16(2):27. http://www.ecologyandsociety.org/vol16/iss2/ $\underline{\operatorname{art} 271}$

Brito, L. 2012. Analyzing sustainable development goals. Science 336:1396. http://dx.doi.org/10.1126/science.1224531 
Brock, W. A., and S. R. Carpenter. 2007. Panaceas and diversification of environmental policy. Proceedings of the National Academy of Sciences of the United States of America 104(39):15206-15211. http://dx.doi.org/10.1073/pnas.0702096104

Brock, W., F. Westley, and M. Scheffer. 2003. Slow response of societies to new problems: causes and costs. Ecosystems 6:493502 .

Butchart, S. H. M., M. Walpole, B. Collen, A. von Strien, J. P. W. Scharleman, R. E. A. Almond, J. E. M. Baillie, B. Bomhard, C. Brown, J. Bruno, K. E. Carpenter, G. M. Carr, J. Chanson, A. M. Chenery, J. Csirke, N. C. Davidson, F. Dentener, M. Foster, A. Galli, J. N. Galloway, P. Genovesi, R. D. Gregory, M. Hockings, V. Kapos, J.-F., Lamarque, F. Leverington, J. Loh, M. A. McGeoh, L. McRae, A. Minasyan, M. H. Morcillo, T. E. E. Oldfield, D. Pauly, S. Quader, C. Revenga, J. R. Sauer, B. Skolnik, D. Spear, D. Stanwell-Smith, S. N. Stuart, A. Symes, M. Tierney, T. D. Tyrrell, J.-C. Vié, and R. Watson. 2010. Global biodiversity: indicators of recent declines. Science 328:1164-1168. http://dx. doi.org/10.1126/science.1187512

Chapin, F. S., S. R. Carpenter, G. P. Kofinas, C. Folke, N. Abel, W. C. Clark, P. Olsson, M. S. Smith, B. Walker, O. R. Young, F. Berkes, R. Biggs, J. M. Grove, R. L. Naylor, E. Pinkerton, W. Steffen, and F. J. Swanson. 2010. Ecosystem stewardship: sustainability strategies for a rapidly changing planet. Trends in Ecology \& Evolution 25(4):241-249. http://dx.doi.org/10.1016/j. $\underline{\text { tree.2009.10.008 }}$

Crutzen, P. J. 2002. Geology of mankind. Nature 415(6867):2324. http://dx.doi.org/10.1038/415023a

Daily, G. C., S. Polasky, J. Goldstein, P. M. Kareiva, H. A. Mooney, L. Pejchar, T. H. Ricketts, J. Salzman, and R. Shallenberger. 2009. Ecosystem services in decision making: time to deliver. Frontiers in Ecology and the Environment 7(1):21-28. http://dx.doi.org/10.1890/080025

Davis K. F., P. D’Odorico, F. Laio, and L. Ridolfi. 2013. Global spatio-temporal patterns in human migration: a complex network perspective. PLoS One 8:e53723. http://dx.doi.org/http://dx.doi. org/10.1371/journal.pone.0053723

Ellis E. C., K. Klein Goldewijk, S. Siebert, D. Lightman, and N. Ramankutty. 2010. Anthropogenic transformation of the biomes, 1700 to 2000. Global Ecology and Biogeography 19:589-606.

Espinoza, J. L., and H. Vredenburg. 2010. Towards a model of wind energy industry development in industrial and emerging economies. Global Business and Economics Review 12(3):203-229. http://dx.doi.org/10.1504/GBER.2010.034894

Finnemore, M., and K. Sikkink. 1998. International norm dynamics and political change. International Organization 52 (4):887-917. http://dx.doi.org/10.1162/002081898550789

Folke, C., T. Hahn, P. Olsson, and J. Norberg. 2005. Adaptive governance of social-ecological systems. Annual Review of Environment and Resources 30:441-473. http://dx.doi.org/10.1146/ annurev.energy.30.050504.144511

Folke, C., Å. Jansson, J. Rockström, P. Olsson, S. R. Carpenter, F. S. Chapin, A.-S. Crépin, G. Daily, K. Danell, J. Ebbesson, T. Elmqvist, V. Galaz, F. Moberg, M. Nilsson, H. Österblom, E.
Ostrom, Å. Persson, G. Peterson, S. Polasky, W. Steffen, B. Walker, and F. Westley. 2011. Reconnecting to the biosphere. Ambio 40:719-738. http://dx.doi.org/10.1007/s13280-011-0184-y

Galaz, V., B. Crona, H. Österblom, P. Olsson, and C. Folke. 2012. Polycentric systems and interacting planetary boundariesemerging governance of climate change-ocean acidificationmarine biodiversity. Ecological Economics 81:21-32. http://dx. doi.org/10.1016/j.ecolecon.2011.11.012

Galaz, V., P. Olsson, T. Hahn, C. Folke, and U. Svedin. 2008. The problem of fit among biophysical systems, environmental and resource regimes, and broader governance systems: insights and emerging challenges. In O. R. Young, L. A. King, and $\mathrm{H}$. Schroeder, editors. Institutions and environmental change: principal findings, applications, and research frontiers. MIT Press, Cambridge, Massachusetts, USA. http://dx.doi.org/10.7551/ mitpress/9780262240574.003.0005

Griggs, D., M. Stafford-Smith, O. Gaffney, J. RockstrÃ $\rrbracket$ m, M. C. $\tilde{A}$-hman, P. Shyamsundar, W. Steffen, G. Glaser, N. Kanie, and I. Noble. 2013. Policy: sustainable development goals for people and planet. Nature 495:305-307. http://dx.doi.org/10.1038/495305a

Grin, J., J. Rotmans, J. Schot, F. Geels, and D. Loorbach. 2010. Transitions to sustainable development: new directions in the study of long term transformative change. Routledge, New York, USA.

Gromet, D. M., H. Kunreuther, and R. P. Larrick. 2013. Political ideology affects energy-efficiency attitudes and choices. Proceedings of the National Academy of Sciences of the United States of America 110(23):9314-9319. http://dx.doi.org/10.1073/ pnas. 1218453110

Halpern, B. S., S. Walbridge, K. A. Selkoe, C. V. Kappel, F. Micheli, C. D’Agrosa, J. F. Bruno, K. S. Casey, C. Ebert, H. E. Fox, R. Fujita, D. Heinemann, H. S. Lenihan, E. M. P. Madin, M. T. Perry, E. R. Selig, M. Spalding, R. Steneck, and R. Watson. 2008. A global map of human impact on marine ecosystems. Science 319:948-952. http://dx.doi.org/10.1126/science.1149345

Helbing, D. 2013. Globally networked risks and how to respond. Nature 497:51-59. http://dx.doi.org/10.1038/nature12047

Hertel, T.W., A. A. Golub, A. D. Jones, M. O'Hare, R. J. Plevin, and D. M. Kammen. 2010. Effects of US maize ethanol on global land use and greenhouse gas emissions: estimating marketmediated responses. Bioscience 60:223-231. http://dx.doi. org/10.1525/bio.2010.60.3.8

Hughes, T. P., S. Carpenter, J. Rockström, M. Scheffer, and B. Walker. 2013. Multiscale regime shifts and planetary boundaries. Trends in Ecology and Evolution 28:389-395. http://dx.doi. org/10.1016/j.tree.2013.05.019

Intergovernmental Panel on Climate Change (IPCC). 2013. Working Group I contribution to the IPCC fifth assessment report-summary for policymakers. Pages 1-36 in Climate change 2013: the physical science basis.

Janssen, M. A., R. Holahan, A. Lee, and E. Ostrom. 2010. Lab experiments for the study of social-ecological systems. Science 328:613-617. http://dx.doi.org/10.1126/science.1183532

Kambhu, J., S. Weidman, and N. Krishnan. 2007. New directions for understanding systemic risk. Economic Policy Review. 
Lade, S. J., A. Tavoni, S. A. Levin, and M. Schlüter. 2013. Regime shifts in a social-ecological system. Theoretical Ecology 6:359372. http://dx.doi.org/10.1007/s12080-013-0187-3

Lambin, E. F., and P. Meyfroidt. 2011. Global land use change, economic globalization, and the looming land scarcity. Proceedings of the National Academy of Sciences of the United States of America 108(9):3465-3472. http://dx.doi.org/10.1073/ pnas. 1100480108

Larigauderie, A., A.-H. Prieur-Richard, G. M. Mace, M. Lonsdale, H. A. Mooney, L. Brussaard, D. Cooper, W. Cramer, P. Daszak, S. Díaz, A. Duraiappah, T. Elmqvist, D. P. Faith, L. E. Jackson, C. Krug, P. W. Leadley, P. Le Prestre, H. Matsuda, M. Palmer, C. Perrings, M. Pulleman, B. Reyers, E. A. Rosa, R. J. Scholes, E. Spehn, B. Turner, II, and T. Yahara. 2012. Biodiversity and ecosystem services science for a sustainable planet: the DIVERSITAS vision for 2012-20. Current Opinion in Environmental Sustainability 4:101-105. http://dx.doi.org/10.1016/ j.cosust.2012.01.007

Leach, M., J. Rokstrom, P. Raskin, I. Scoones, A. C. Stirling, A. Smith, J. Thompson, E. Millstone, A. Ely, E. Arond, C. Folke, and P. Olsson. 2012. Transforming innovation for sustainability. Ecology and Society 17(2):11. http://dx.doi.org/10.5751/ ES-04933-170211

Lenton, T. M., H. Held, E. Kriegler, J. W. Hall, W. Lucht, S. Rahmstorf, and H. J. Schellnhuber. 2008. Tipping elements in the Earth's climate system. Proceedings of the National Academy of Sciences of the United States of America 105:1786-1793. http:// dx.doi.org/10.1073/pnas.0705414105

Lieberman, E. S. 2011. The perils of polycentric governance of infectious disease in South Africa. Social Science \& Medicine 73:676-684. http://dx.doi.org/10.1016/j.socscimed.2011.06.012

Loorbach, D., and J. Rotmans. 2010. The practice of transition management: examples and lessons from four distinct cases. Futures 42(3):237-246. http://dx.doi.org/10.1016/j.futures.2009.11.009

Lovell, H., and D. MacKenzie. 2011. Accounting for carbon: the role of accounting professional organisations in governing climate change. Antipode 43(3):704-730. http://dx.doi.org/10.1111/ j.1467-8330.2011.00883.x

Meyfroidt, P., E. F. Lambin, K.-H. Erb, and T. W. Hertel. 2013. Globalization of land use: distant drivers of land change and geographic displacement of land use. Current Opinion in Environmental Sustainability 5:438-444. http://dx.doi.org/10.1016/ j.cosust.2013.04.003

Millennium Ecosystem Assessment (MEA). 2006. Millennium Ecosystem Assessment. Ecosystems and human well-being: synthesis. Island Press, Washington D.C., USA.

Österblom, H., and U. R. Sumaila. 2011. Toothfish crises, actor diversity and the emergence of compliance mechanisms in the Southern Ocean. Global Environmental Change 21(3):972-982. http://dx.doi.org/http://dx.doi.org/10.1016/j.gloenvcha.2011.04.013

Ostrom, E. 1990. Governing the commons: the evolution of institutions for collective action. Cambridge University Press, Cambridge, UK. http://dx.doi.org/10.1017/CBO9780511807763
Ostrom, E. 1999. Institutional rational choice: an assessment of the institutional analysis and development framework. Pages 3571 in P. A. Sabatier and C. M. Weible, editors. Theories of the Policy Process. Westview Press, Boulder, Colorado, USA.

Ostrom, E. 2009. A general framework for analyzing sustainability of social-ecological systems. Science 325 (5939):419-422. http://dx.doi.org/10.1126/science.1172133

Ostrom, E. 2010. Polycentric systems for coping with collective action and global environmental change. Global Environmental Change 20(4):550-557. http://dx.doi.org/10.1016/j.gloenvcha.2010.07.004

Ostrom, E., T. Dietz, N. Dolzak, P. C. Stern, S. Stonich, and E. U. Weber. 2002. The drama of the commons. The National Academies Press, Washington, D.C., USA.

Ostrom, E., R. Gardner, and J. Walker. 1994. Rules, games and common-pool resources. University of Michigan Press, Detroit, Michigan, USA.

Paolucci, M., D. Kossman, R. Conte, P. Lukowitz, P. Argyrakis, A. Blandford, G. Bonelli, S. Anderson, S. de Freitas, B. Edmonds, N. Gilbert, M. Gross, J. Kohlhammer, P. Koumatsakos, A. Krause, B.-O. Linnér, P. Slussallek, O. Sorkine, R. W. Summer, and D. Helbing. 2012. Towards a living earth simulator. European Physical Journal Special Topics 214:77-108. http://dx.doi. org/10.1140/epjst/e2012-01689-8

Parris, T. M., and R. W. Kates. 2003a. Characterizing a sustainability transition: goals, targets, trends, and driving forces. Proceedings of the National Academy of Sciences of the United States of America 100(14):8068-8073. http://dx.doi.org/http://dx. doi.org/10.1073/pnas. 1231336100

Parris, T. M., and R. W. Kates. 2003b. Characterizing and measuring sustainable development. Annual Review of Environment and Resources 28:559-586. http://dx.doi.org/http:// dx.doi.org/10.1146/annurev.energy.28.050302.105551

Pereira, H. M., S. Ferrier, M. Walters, G. N. Geller, R. G. H. Jongman, R. J. Scholes, M. W. Bruford, N. Brummitt, S. H. M. Butchart, A. C. Cardoso, N. C. Coops, E. Dulloo, D. P. Faith, J. Freyhof, R. D. Gregory, C. Heip, R. Höft, G. Hurtt, W. Jetz, D. S. Karp, M. A. McGeoch, D. Obura, Y. Onoda, N. Pettorelli, B. Reyers, R. Sayre, J. P. W. Scharlemann, S. N. Stuart, E. Turak, M. Walpole, and M. Wegmann. 2013. Essential biodiversity variables. Science 339:277-278. http://dx.doi.org/10.1126/science.1229931

Perrings, C., A. Duraiappah, A. Larigauderie, and H. Mooney. 2011. The biodiversity and ecosystem services science-policy interface. Science 331(4):1139-1140. http://dx.doi.org/10.1126/ science. 1202400

Pinker, S. 2006. How the mind works. Annals of the New York Academy of Sciences of the United States of America 882(1):119127.

Poteete, A. R., M. A. Janssen, and E. Ostrom. 2010. Working together: collective action, the commons, and multiple methods in practice. Princeton University Press, New York, USA.

Reid, W. V, D. Chen, L. Goldfarb, H. Hackmann, Y. T. Lee, K. Mokhele, E. Ostrom, K. Raivio, J. Rockström, H. J. Schellnhuber, and A. Whyte. 2010. Earth System Science for global 
sustainability: grand challenges. Science 330:916-917. http://dx. doi.org/10.1126/science. 1196263

Reyers, B., R. Biggs, G. S. Cumming, T. Elmqvist, A. P. Hejnowicz, and S. Polasky. 2013. Getting the measure of ecosystem services: a social-ecological approach. Frontiers in Ecology and the Environment 11(5):268-273. http://dx.doi.org/10.1890/120144

Rockström, J., W. Steffen, K. Noone, Å. Persson, F. S. Chapin, III, E. F. Lambin, T. M. Lenton, M. Scheffer, C. Folke, H. J. Schellnhuber, B. Nykvist, C. A. de Wit, T. Hughes, S. van der Leeuw, H. Rodhe, S. Sörlin, P. K. Snyder, R. Costanza, U. Svedin, M. Falkenmark, L. Karlberg, R. W. Corell, V. J. Fabry, J. Hansen, B. Walker, D. Liverman, K. Richardson, P. Crutzen, and J. A. Foley. 2009. A safe operating space for humanity. Nature 461:472475. http://dx.doi.org/10.1038/461472a

Rothstein, B. 2000. Trust, social dilemmas and collective memories. Journal of Theoretical Politics 12(4):477-501. http:// dx.doi.org/10.1177/0951692800012004007

Sachs, J. D. 2012. From Millennium Development Goals to sustainable development goals. Lancet 379(9832):2206-2211. http://dx.doi.org/10.1016/S0140-6736(12)60685-0

Scheffer, M., S. Carpenter, J. A. Foley, C. Folke, and B. Walker. 2001. Catastrophic shifts in ecosystems. Nature 413:591-596. http://dx.doi.org/10.1038/35098000

Schultz, M., J. Rockström, M. C. Öhman, S. Cornell, Å. Persson, and A. V. Norström. 2013. Human prosperity requires global sustainability - a contribution to the post 2015 agenda and the development of sustainable development goals. Report for the Nordic Council of Ministers, Stockholm Resilience Centre, Sweden.

Searchinger, T., R. A. Heimlich, F. Houghton, A. Dong, J. Elobeid, J. Fabiosa, S. Tokgoz, D. Hayes, and T.-H. Yu. 2008. Use of U.S. croplands for biofuels increases greenhouse gases through emissions from land-use change. Science 319(5867):1238-1240.

Seto, K. C., A. Reenberg, C. G. Boone, M. Fragkias, D. Haase, T. Langanke, P. Marcotullio, D. K. Munroe, B. Olah, and D. Simon. 2012. Urban land teleconnections and sustainability. Proceedings of the National Academy of Sciences of the United States of America 109:7687-7692. http://dx.doi.org/10.1073/ pnas. 1117622109

Seyfang, G., and A. Haxeltine. 2012. Growing grassroots innovations: exploring the role of community-based initiatives in governing sustainable energy transitions. Environment and Planning C: Government and Policy 30(3):381-400. http://dx.doi. org/10.1068/c10222

Smith, A., and R. Raven. 2010. Niche protection in transitions to sustainability. Research Policy 5:1-27.

Steffen, W., M. O. Andreae, B. Bolin, P. M. Cox, P. J. Crutzen, U. Cubasch, H. Held, N. Nakicenovic, R. J. Scholes, L. TalaueMcManus, and B. L. Turner II. 2004. Abrupt changes: the Achilles' heels of the Earth System. Environment 46(3):8-20. http://dx.doi.org/http://dx.doi.org/10.1080/00139150409604375

Steffen, W., Å. Persson, L. Deutsch, J. Zalasiewicz, M. Williams, K. Richardson, C. Crumley, P. Crutzen, C. Folke, L. Gordon, M. Molina, V. Ramanathan, J. Rockström, M. Scheffer, H. J.
Schellnhuber, and U. Svedin. 2011. The Anthropocene: from global change to planetary stewardship. AMBIO 40:739-761. http://dx.doi.org/10.1007/s13280-011-0185-x

United Nations Environment Programme (UNEP). 2012. Measuring progress: environmental goals \& gaps. United Nations Press, Nairobi, Kenya.

van der Leeuw, S. 2010. The archeology of innovation: lessons for our times. Pages 33-53 in Innovation: perspectives for the 21st century. BBVA, Madrid, Spain.

Villoria, N. B., and T. W. Hertel. 2011. Geography matters: international trade patterns and the indirect land use effects of biofuels. American Journal of Agricultural Economics 93:919-935. http://dx.doi.org/10.1093/ajae/aar025

Vörösmarty, C. J., P. B. McIntyre, M. O. Gessner, D. Dudgeon, A. Prusevich, P. Green, S. Glidden, S. E. Bunn, C. A. Sullivan, C. R. Liermann, and P. M. Davies. 2010. Global threats to human water security and river biodiversity. Nature 467:555-561. http:// dx.doi.org/10.1038/nature09440

Waage, J., R. Banerji, O. Campbell, E. Chirwa, G. Collender, V. Dieltiens, A. Dorward, P. Godfrey-Faussett, P. Hanvoravongchai, G. Kingdon, A. Little, A. Mills, K. Mulholland, A. Mwinga, A. North, W. Patcharanarumol, C. Poulton, V. Tangcharoensathien, and E. Unterhalter. 2010. The Millennium Development Goals: a cross-sectoral analysis and principles for goal setting after 2015. Lancet 376(9745):991-1023. http://dx.doi.org/http://dx.doi.org/10.1016/ $\underline{\mathrm{S} 0140-6736(10) 61196-8}$

Walker, B., S. Barrett, S. Polasky, V. Galaz, C. Folke, G. Engström, F. Ackerman, K. Arrow, S. Carpenter, K. Chopra, G. Daily, P. Ehrlich, T. Hughes, N. Kautsky, S. Levin, K.-G. Mäler, J. Shogren, J. Vincent, T. Xepapadeas, and A. de Zeeuw. 2009. Looming global-scale failures and missing institutions. Science 325:13451346. http://dx.doi.org/10.1126/science. 1175325

Westley, F., and N. Antadze. 2010. Making a difference strategies for scaling social innovation for greater impact. The Innovation Journal: The Public Sector Innovation Journal 15:1-20.

Westley, F., P. Olsson, C. Folke, T. Homer-Dixon, H. Vredenburg, D. Loorbach, J. Thompson, M. Nilsson, E. Lambin, J. Sendzimir, B. Banerjee, V. Galaz, and S. Leeuw. 2011. Tipping toward sustainability: emerging pathways of transformation. AMBIO 40 (7):762-780. http://dx.doi.org/10.1007/s13280-011-0186-9

Wolbring, G., R. Mackay, T. Rybchinski, and J. Noga. 2013. Disabled people and the post-2015 development goal agenda through a disability studies lens. Sustainability 5(10):4152-4182. http://dx.doi.org/http://dx.doi.org/10.3390/su5104152

Young, O. R. 1994. International governance: protecting the environment in a stateless society. Cornell University Press, New York, USA.

Young, O. R., F. Berkhout, G. C. Gallopín, M. A. Janssen, E. Ostrom, and S. van der Leeuw. 2006. The globalization of socioecological systems: an agenda for scientific research. Global Environmental Change 16:304-316. http://dx.doi.org/10.1016/j. gloenvcha.2006.03.004 